\title{
Latest Developments Aiming an Integrated Management Systems Tool Focusing Maturity Assessment
}

\author{
J. P. T. Domingues ${ }^{1,2}$, P. Sampaio ${ }^{2}$ and P. M. Arezes ${ }^{2}$ \\ ${ }^{1}$ Chemichal Laboratory Marques Ferreira, Delphi Complex Ed. 3, Braga, Portugal \\ ${ }^{2}$ Department of Production and Systems, University of Minho, Guimarães, Portugal \\ ( pedrodomin@sapo.pt; paulosampaio@dps.uminho.pt; parezes@dps.uminho.pt )
}

\begin{abstract}
Integrated management systems (IMS) widespread among companies due to the release, by international entities, of management sub-systems implementation standards. The integration level achieved by the IMS varies from company to company. Rating the integration level is crucial information. Maturity models have been implemented in several business, product development and in management sub-systems context in order to guide the company to an ultimate excellence level. An IMS maturity model development is, currently, aimed by researchers and a real need in companies. It is intended in this paper to report the efforts that are being made and the methodologies that are being followed to develop such a model. Additionally, it is also intended to present a preliminary model version. Keywords - IMS, experts, maturity
\end{abstract}

\section{INTRODUCTION}

Management systems integration had been reported in several renowned international journals, in several books and is, currently, a subject or topic on the most prestigious conferences related to Quality, Environment and Occupational Health and Safety $[1-8,18]$. From an initial period where mostly theoretical papers on the subject dominate [9-11], a more practical approach had been reported in the last few years sustained on surveys, interviews and case studies [1, 12, 13]. Conceptual models have been proposed based on the, yet scarce, available results. Academic interest is focused on the development of a tool/methodology that allows one to evaluate the degree of integration in those companies that implement an IMS. An international IMS implementation standard did not been released at the moment. ISO Advisory Group early (1998) recommended no merging of management systems standards stating, in their Press release, 'Do not merge ISO 9000 (quality) and ISO 14000 (environment) into one family of standards, but make it easier for businesses to implement both by making them more compatible and get the job finished by 2000/2001' [14]. The ISO 9001 and ISO 14001 revisions had improved the standards compatibility and recent results show that companies found sub-systems standards integration to be very easy or easy to integrate [15]. The questions that companies would like to be answered are: Could my IMS be more efficient? What should I do to achieve excellence in integrated management? We are leading a project with the aim of developing a tool that rates the IMS efficiency and maturity. A literature review about the IMS subject and identification of key parameters affecting IMS maturity and efficiency, allow the development of a survey carried out with companies that had implemented an IMS in order to check the validity of those assumptions. Based on the analysis of the information gathered in the previous phase, a questionnaire was performed with a group of academic and industry experts, with the aim of weighting the parameters that were chosen to classify and rate IMS maturity and efficiency levels.

\section{METHODOLOGY}

An online survey with 30 questions was held focusing Portuguese companies with more than one certified management sub-system according to the following standards: ISO 9001, ISO 14001 and OHSAS 18001/NP 4397. The following results were supported on 53 validate answers. The statements and questions that sustained the survey are presented in the Appendix. Some of these results were collected and submitted to the appreciation of an experts group to assess in what extent each parameter could reflect the management system integration level. Each expert was asked to classify each parameter according to the integration level (ranging from minimum to maximum) it represents. If the expert felt that the parameter do not represent any kind of integration level he may choose the option- 'Non Relevant Parameter'. The experts' survey design was based on the companies' survey results and on the questions/statements that provided the most coherent results. As been stated earlier, from the results presented in the research conducted with the companies, a new survey was developed (each new statement based on previous companies survey statements acc. to Table 1) focused in a group of experts.

TABLE 1: EXPERTS SURVEY STATEMENTS GENESIS

\begin{tabular}{|c|c|c|}
\hline Companies survey & & Experts Survey \\
\hline Q28; Q29; Q30 & $\rightarrow$ & S1 \\
\hline S15; S18 & $\rightarrow$ & S2 \\
\hline S19 & $\rightarrow$ & S3 \\
\hline S10; Q22 & $\rightarrow$ & S4a \\
\hline S16; Q22 & $\rightarrow$ & S4b \\
\hline Q27 & $\rightarrow$ & S5 \\
\hline Q24 & $\rightarrow$ & S6 \\
\hline Q26 & $\rightarrow$ & S7 \\
\hline S9 & $\rightarrow$ & S8 \\
\hline Q13 & $\rightarrow$ & S9 \\
\hline Q21 & $\rightarrow$ & S10 \\
\hline S5; S11 & $\rightarrow$ & S11 \\
\hline S8; S14 & $\rightarrow$ & S12 \\
\hline Q23; Q25 & $\rightarrow$ & S13 \\
\hline
\end{tabular}


Table 1 shows the methodology followed to develop the experts survey. Ten academic and industry experts were invited to answer the 13 statements survey that are displayed in the Appendix.

\section{RESULTS}

\section{A. Companies Survey}

Tables 2 to 3 and Fig. 1 and 2 characterize the companies' surveyed sample. Survey companies were mainly located at Lisbon region (43\%), Center (30\%) and North (19\%) of Portugal, generically matching Portuguese companies reality related to geographical location [16].

Table 2 shows that $58 \%$ of the respondent companies were companies with between 50 to 249 workers.

TABLE 2: NUMBER OF EMPLOYEES (\%)

\begin{tabular}{|c|c|c|c|}
\hline$\leq \mathbf{9}$ & $\mathbf{1 0}$ to $\mathbf{4 9}$ & $\mathbf{5 0}$ to 249 & $\geq \mathbf{2 5 0}$ \\
\hline $2 \%$ & $9 \%$ & $58 \%$ & $31 \%$ \\
\hline
\end{tabular}

Table 3 presents the results related to IMS typology adopted by the respondent companies and the Portuguese companies results [16]. The two major typologies, QMS plus EMS and QMS plus EMS plus OHSMS are present in the surveyed sample and are the most reported ones at national level.

\begin{tabular}{|c|c|c|c|c|c|}
\hline & QMS+EMS+ & QMS+ & QMS+ & EMS+OHSMS & Other \\
\hline & OHSMS & EMS & OHSMS & & \\
\hline Survey & 77 & 8 & 0 & 0 & 15 \\
\hline National [16] & 0,69 & 0,76 & 0,28 & 0,08 & --- \\
\hline
\end{tabular}

Analysis of Table 4 suggests that four of the activities sectors present on the national Top 5 [16] are present also in the surveyed sample (Table 4). This fact suggests that, despite of the inexistence of conclusive available results, an increase of EMS and OHSMS certification indeed implies an increase in the number of integrated management systems, supporting what as been stated in [5].

TABLE Y: TOP 4- ACTIVITY SECTOR (\%)

\begin{tabular}{|c|c|c|c|c|c|}
\hline $\begin{array}{c}\text { Construc } \\
.\end{array}$ & Metallurgy & $\begin{array}{c}\text { Water } \\
\text { Supply }\end{array}$ & Educa & $\begin{array}{c}\text { Other } \\
\text { Services }\end{array}$ & $\begin{array}{c}\text { Transp, } \\
\text { Com, Log. }\end{array}$ \\
\hline 22 & 11 & 11 & 9 & 9 & 9 \\
\hline
\end{tabular}

Fig. 1 to 2 present available results considering a two parameters approach.

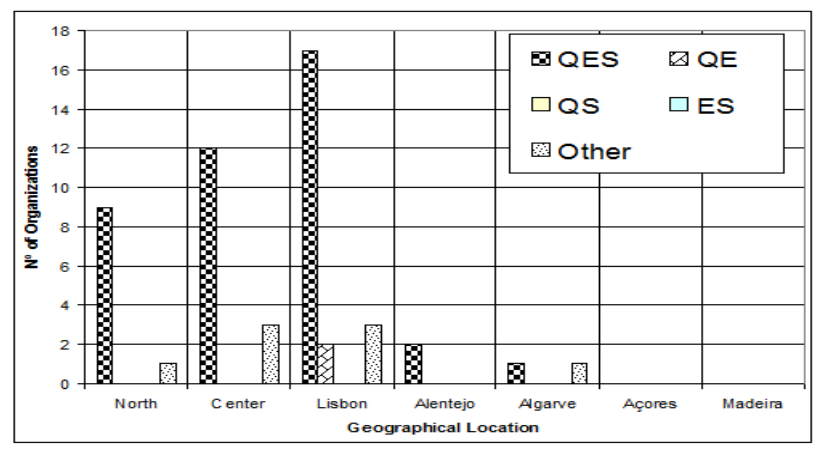

Fig. 1. Surveyed companies location versus IMS typology
Based on the available graphical displayed results, a relationship between the two parameters studied on each figure does not exist, but a suitable statistical analysis should be performed to support this assumption. Considering Figures 1 to 2, one may see that surveyed companies partially match the national certified companies [16]. A considerable resemblance between the results from the survey and those described by [16] does exist.

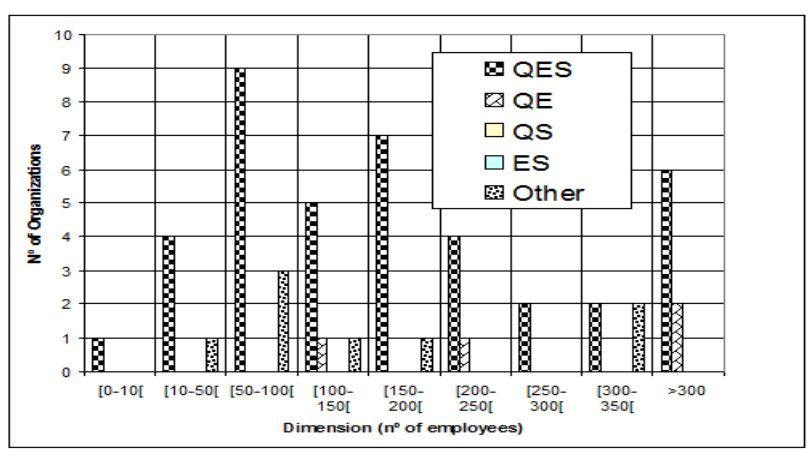

Fig. 2. Surveyed companies dimension versus IMS typology

Fig. 3 and 4 present the results (percentage) of the statements 5 to 20 from the survey carried out with the companies.

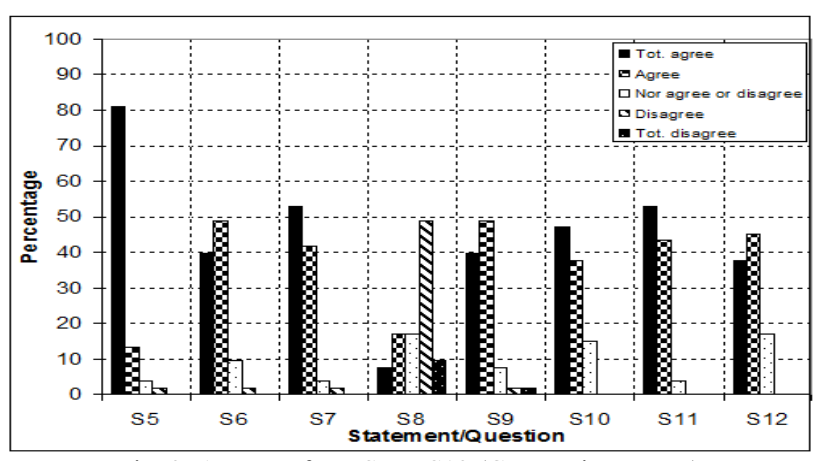

Fig. 3. Answers from S5 to S12 (Companies survey)

With Q13 exception, all the results present a high level of homogeneity.

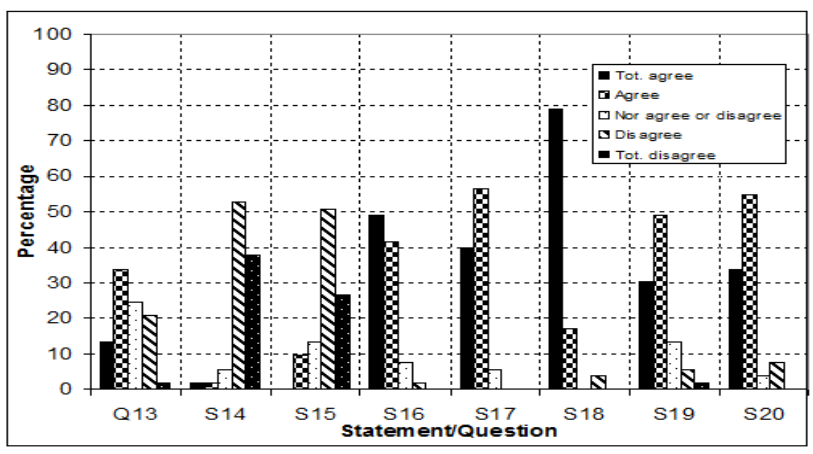

Fig. 4. Answers from Q13 to S20 (Companies survey)

These results reveal strong indications that in all surveyed companies integrated policies do exist, an integration concept had been taken into account during 
implementation and training/information had been provided to top management concerning the integration process. Furthermore, based on available results, it seems possible to conclude that an IMS responsible is clearly defined in the organizational structure and EMS and OHSMS managers are empowered to discuss and implement suitable corrective and preventive actions, being their authority not residual.

Results shown in Fig. 5 reveal that IMS responsible found easy or reasonable easy, to integrate the standards. This fact is certainly related to the efforts developed by ISO commission in order to improve the standards compatibility.

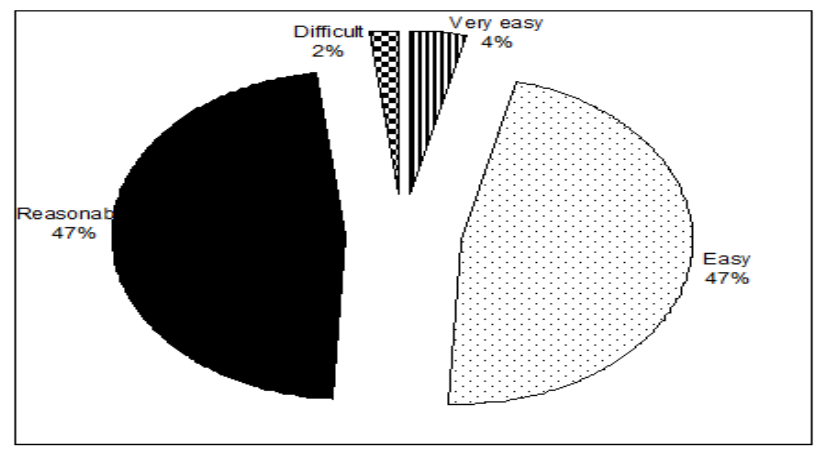

Fig. 5. Results from S21

Concerning the perceived integration level (Fig. 6) of the implemented IMS, just $6 \%$ of the respondents considered that a total/maximum integration level was reached.

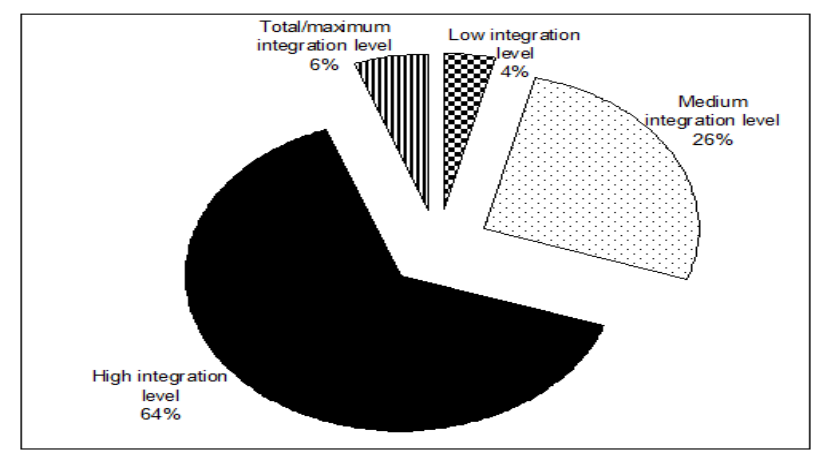

Fig. 6. Results from S25

The most common implementation strategy adopted by the surveyed companies is the sequential standards implementation (64\%). Results from statement 27, where companies were asked if an integration concept was taken into account during implementation revealed an almost fifty/fifty answer typology - 55\% answered that indeed a integration concept was taken into account. Table 5 shows that internal or mainly internal motivations, benefits and obstacles were the most reported one.

TABLE 5: MOTIVATIONS, BENEFITS AND OBSTACLES

\begin{tabular}{|c|c|c|c|}
\hline & Motivations & Benefits & Obstacles \\
\hline Internal-Mainly int. & $23 \%-51 \%$ & $17 \%-64 \%$ & $43 \%-43 \%$ \\
\hline External- Mainly ext. & $4 \%-22 \%$ & $4 \%-15 \%$ & $6 \%-8 \%$ \\
\hline
\end{tabular}

\section{B. Experts Survey}

Six experts effectively answer the survey (Table 6).

TABLE 6: RESULTS FROM SURVEYED EXPERTS

\begin{tabular}{|c|c|c|c|c|c|c|c|}
\hline Sta & E1 & E2 & E3 & E4 & E5 & E6 & W \\
\hline S1 & High & High & High & Rea. & High & High & High \\
\hline S2 & High & High & Low & High & High & High & High \\
\hline S3 & Max. & High & High & Max. & High & High & Max. \\
\hline S4a & High & Max. & High & High & High & High & High \\
\hline S4b & High & High & High & High & High & Rea. & High \\
\hline S5 & Low & Rea. & Max. & Max. & Rea. & Rea. & Rea. $\uparrow$ \\
\hline S6 & Low & Rea. & High & Rea. & Rea. & Max. & Rea. \\
\hline S7 & Low & Rea. & Rea. & Rea. & Rea. & High & Rea. \\
\hline S8 & High & High & High & Max. & Max. & High & Max. \\
\hline S9 & High & Rea. & High & High & High & Low & Rea. \\
\hline S10 & Low & High & Low & Min. & Max. & Rea. & Low. $\uparrow$ \\
\hline S11 & Rea. & Rea. & Max. & Max. & Max. & Max. & High \\
\hline S12 & Rea. & Max. & High & Rea. & Low. & Min. & Rea. \\
\hline S13 & Rea. & Rea. & High & Max. & High & Max. & High $\downarrow$ \\
\hline
\end{tabular}

Obs: Min.- Minimum; Low; Rea.- Reasonable; High; Max.- Maximum; W- Weight

Fig. 7 and 8 display the results from statement 1 to statement 6 (Fig 7) and to statement 7 to 13 (Fig. 8). Statements 10 and 12 did not achieved a consensus between the experts revealing that, the fact of IMS responsible found easy to integrate the sub-systems standards, is not a crucial parameter determining the integration level. Documental integration and bureaucratization are not found to be a parameter revealing a clear integration degree.

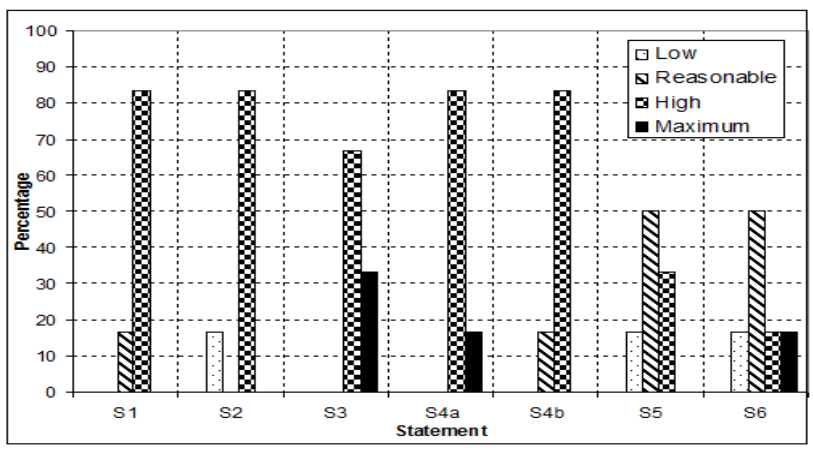

Fig. 7. Answers from S1 to S6 (Experts survey)

Results suggest that internal motivations, integrated indicators, top management integrated vision, objectives alignment and same organizational tools and methodologies are found to be parameters revealing a high integration level by the experts.

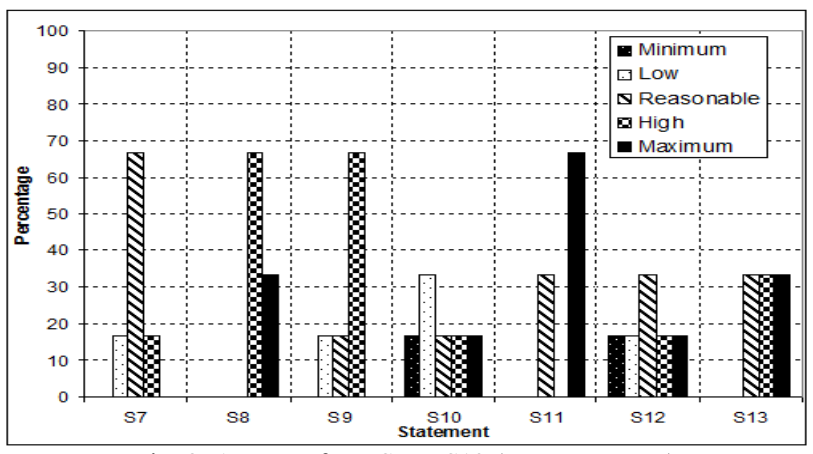

Fig. 8. Answers from S7 to S13 (Experts survey) 


\section{DISCUSSION}

A preliminary model of a tool focusing maturity assessment had been reported in [17]. Available results reveal some common organizational features between all respondent companies, namely, integrated policies, clear definition from an IMS responsible, non residual authority by EMS and/or OHSMS responsible, top management integrated vision and the perception that IMS is an add value to the company. The group of experts weighted the policies and management procedures integration as a high level integration indicative. The perception of IMS as an add value had been classified as an indication of high integration level. Internal or mainly internal motivations, obstacles and benefits had been suggested by several authors as an indication of high integration level. Some papers reported internal motivations as the "true ones" and those that developed more benefits on the long range. Experts' survey classified internal motivations for IMS implementation as a parameter revealing a high integration level. Integration level perceived matches considerably with the implemented organizational structure. Nevertheless, the achievement of an ultimate excellence level is just pointed out by a residual number of companies $(6 \%)$ suggesting that this level is not perceived by IMS responsible. According to these results we may present an update from the preliminary model reported in [17] based on the Crosby CMMi maturity model. This proposal is based on the parameters or key process areas (KPA) selected based on literature review. These KPA are placed on a determined level (1Uncertainty; 2- Awakening; 3- Enlightment; 4- Wisdom; 5- Certainty) based on the answers collected from the companies survey. To each parameter a weight factor (16) is ascribed (Table 7). KPA that are found to be critical are labeled with *. Companies evaluating IMS maturity level according to this tool are obliged to comply with these critical KPA in order to access the upper level.

TABLE 7: KPA, LEVELS AND WEIGHT

\begin{tabular}{|l|c|c|c|}
\hline \multicolumn{1}{|c|}{ Statement/Parameter/KPA } & Lev & Weig. & Obs. \\
\hline Integrated policies & 1 & $\mathrm{x} 4$ & KPA.1* \\
\hline Top management integrated vision & 2 & $\mathrm{x} 5$ & KPA.2 \\
\hline $\begin{array}{l}\text { A guideline or framework supporting } \\
\text { implementation }\end{array}$ & 4 & $\mathrm{x} 3$ & KPA.3 \\
\hline $\begin{array}{l}\text { Top management training related to } \\
\text { IMS }\end{array}$ & 2 & $\mathrm{x} 1$ & KPA.4 \\
\hline $\begin{array}{l}\text { Organizational tools, methodologies } \\
\text { and objectives alignment }\end{array}$ & 3 & $\mathrm{x} 6$ & KPA.5* \\
\hline $\begin{array}{l}\text { Perception that IMS genesis originate } \\
\text { organizational interactions }\end{array}$ & 1 & $\mathrm{x} 1$ & KPA.6 \\
\hline $\begin{array}{l}\text { Non residual authority from EMS } \\
\text { and/or OHSMS managers }\end{array}$ & 4 & $\mathrm{x} 4$ & KPA.7* \\
\hline $\begin{array}{l}\text { Integration concept had been taken } \\
\text { into account }\end{array}$ & 1 & $\mathrm{x} 2$ & KPA.8 \\
\hline Bureaucratized system & 3 & $\mathrm{x} 3$ & KPA.9 \\
\hline Integrated management procedures & 1 & $\mathrm{x} 4$ & KPA.10 \\
\hline Documental integration & 2 & $\mathrm{x} 3$ & KPA.11 \\
\hline Integrated defined objectives & 1 & $\mathrm{x} 5$ & KPA.12 \\
\hline $\begin{array}{l}\text { Clear IMS responsible on the } \\
\text { organizational structure }\end{array}$ & 2 & $\mathrm{x} 4$ & KPA.13* \\
\hline Process monitoring based on KPI's, & 3 & $\mathrm{x} 5$ & KPA.14 \\
\hline
\end{tabular}

\begin{tabular}{|l|c|c|c|}
\hline OPI,s and MPI's & & & \\
\hline Integrated indicators & 5 & $\mathrm{x} 5$ & KPA.15 \\
\hline $\begin{array}{l}\text { Good correlation between real } \\
\text { integration level and that perceived by } \\
\text { workers }\end{array}$ & 4 & $\mathrm{x} 3$ & KPA.16 \\
\hline Integrated audits & 3 & $\mathrm{x} 4$ & KPA.17* \\
\hline Non-integratable item identification & 5 & $\mathrm{x} 3$ & KPA.18 \\
\hline All-In integration sequence & 2 & $\mathrm{x} 3$ & KPA.19 \\
\hline $\begin{array}{l}\text { Overall performance perceived higher } \\
\text { in an integrated context }\end{array}$ & 4 & $\mathrm{x} 5$ & KPA.20 \\
\hline IMS clearly seen as an add value & 1 & $\mathrm{x} 5$ & KPA.21* \\
\hline *- Critical KPA & & & \\
\end{tabular}

Fig. 9 shows, schematically, the KPA distribution.

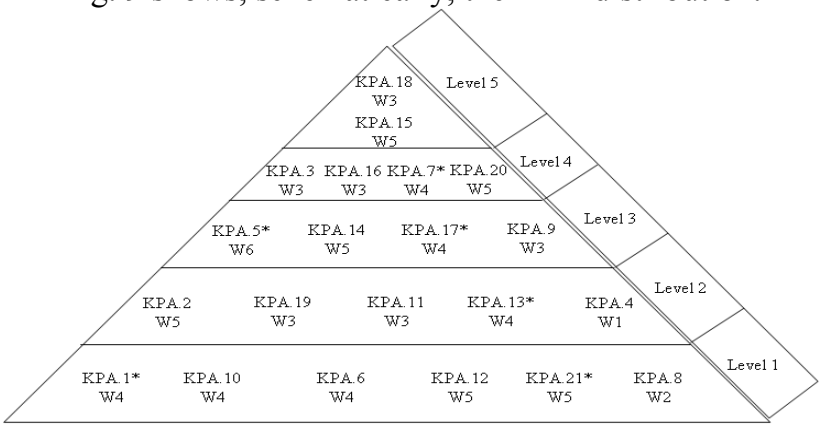

Fig. 9. Scheme from KPA distribution on different levels

Table 8 presents the score and the requirements to be met in order to assess IMS maturity according to Fig. 9. Both the score and requirements should be met. In order to assess the score we should multiply the weight from each KPA that assessed IMS comply with. If the conditions for each level are met, action to be taken is to proceed to the upper level.

TABLE 8: CONDITIONS TO ASSESS IMS MATURITY

\begin{tabular}{|c|c|c|c|c|}
\hline Level & Score & Requisite & Action & Crosby \\
\hline 5 & --- & KPA.18; KPA.15 $\checkmark$ & Excelle. & Certainty \\
\hline 4 & $\geq 60$ & KPA.7* $\checkmark$ & $\uparrow$ level 5 & Wisdom \\
\hline 3 & $\geq 72$ & KPA.17* $\checkmark$ & $\uparrow$ level 4 & Enlightment \\
\hline 2 & $\geq 60$ & KPA.13* $\checkmark$ & $\uparrow$ level 3 & Awakening \\
\hline 1 & $\geq 160$ & KPA.21*KPA.1* $\checkmark$ & $\uparrow$ level 2 & Uncertainty \\
\hline
\end{tabular}

\section{CONCLUSIONS}

Results from two surveys were reported. The first survey focused Portuguese companies with more than one management system certified whereas the other survey focused an experts group with the purpose of weighting some parameters assessed in the companies' survey. Companies' surveyed assures representativeness of geographical location comparing to Portuguese reality. An early stage IMS maturity model has been proposed. Assessment of each KPA may require suitable tools as questionnaires, indicators assessment or new indicators development and surveys.

\section{ACKNOWLEDGMENTS}

We acknowledge Bosch Car Multi. Syst., Delphi, LabMF corporations and to the anonymous companies and experts that answered the surveys. 


\section{REFERENCES}

[1] P. Sampaio, P. Saraiva and J. P. Domingues, "Management systems: Integration or addition?" International Journal of Quality and Reliability Management, Vol. 29, Iss. 4, pp-402-424, 2012.

[2] M. Bernardo, M. Casadesus, S. Karapetrovic and I. Heras, "Do integration difficulties influence management systems integration levels?" Journal of Cleaner Production, Vol. 21, pp. 23-33, 2012 .

[3] J. P. Domingues, P. Sampaio and P. Arezes "Beyond "audit" definition: A framework proposal for integrated management systems" in Proc. the 6I ${ }^{\text {th }}$ IEEE Annual Conference and Expo, 21-25 May, Reno, Nevada, USA, 2011.

[4] J. P. Domingues, P. Sampaio and P. M. Arezes "Management Systems Integration: Should

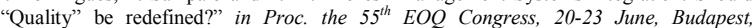
Hungary, 2011.

[5] J. P. Domingues, P. Sampaio and P. M. Arezes "Integrated Management Systems: The vision from the perspective of the OH\&SMS" in Proc. of the SHO 2011,pp. 240-245, 10-11 February, Guimarães, Portugal, 2011 .

[7] M. Asif, O. A. M. Fisscher, E. J Bruijn, "An examination of strategies employed for the integration of management systems" Total Quality Management, Vol. 22, No 6, pp. 648669,2010

[8] M. Celik, "Design of integrated quality and safety management systems (IQSMS) for shipping operations" Safety Science, Vol. 47, pp. 569-577, 2009

[9] J. J. Tarí and J. F. Molina-Azorín, "Integration of quality and environmental management systems: Similarities and the role of the EFQM model" The TQM Journal, Vol. 22, No 6 , pp. $687-701,2010$.

[10] R. B. Pojasek, "Is your integrated management system really integrated?" Environmental Quality Management, Winter, pp. 89-97, 2006.

[11] S. Karapetrovic, "On the concept of a universal audit of quality and environmental management systems" Corporate Social Responsibility and Environmental Management, Vol. 9, pp. 147-156, 2002.

[12] I. A. Beckmerhagen, H. P. Berg, S. V. Karapetrovic and W. O. Willborn, "Integration of management systems: Focus on safety in the nuclear industry" International Journal of Quality and Reliability Management, Vol. 20, Iss. 2, pp-210-228, 2002.

[13] S. Karapetrovic and M. Casadesús, "Implementing environmental with other standardized management systems: Scope, sequence, time and integration" International Journal of Cleaner Production, Vol. 17, pp-533-540, 2009.

[14] ISO Press Release, "Advisory group recommends actions for greater compatibility, but no merging of ISO 9000 and ISO 14000 " in ISO site, 1998-02-19.

[15] J. P. Domingues, P. Sampaio and P. M. Arezes "Integrated management systems: On the path to maturity and efficiency assessment" in Proc. of the SHO 2012, pp. 177-179 February, Guimarães, Portugal, 2012 (Full paper published on CD).

[16] P. Sampaio and P. Saraiva, "Barómetro da Certificação", Edição 5 by CemPalavras (site), 2011.

[17] J. P. Domingues, P. Sampaio and P. M. Arezes "Integração de sistemas de gestão: Dados preliminares no desenvolvimento de uma metodologia para avaliação do nível de maturidade" in Proc. of the ENEGI 2011, pp. 121-129, Guimarães, Portugal, 2011 (Full paper published on $C D$ )

[18] G. Santos, M. Rebelo, S. Barros and M. Pereira "Certification and integration of environment with Quality and Safety- A path to sustained sucess" in INTECHSustainable Development - Authoritative and Leading Edge Content for Environmental Management, Chapter 9, pp. 193-218, 2012

\section{APPENDIX}

\section{A. Companies Survey Structure}

\begin{tabular}{|c|c|c|}
\hline ID & Statement/Question & Possible Answers \\
\hline S1 & The company main activity is: & Unstructured \\
\hline Q2 & How many workers employ the company? & Unstructured \\
\hline Q3 & $\begin{array}{l}\text { Where is geographically located the } \\
\text { company? }\end{array}$ & $\begin{array}{l}\text { North; Center; Lisbon; } \\
\text { Alentejo; Algarve; } \\
\text { Madeira; Açores }\end{array}$ \\
\hline S4 & $\begin{array}{l}\text { The management system is certified } \\
\text { according the following standards: }\end{array}$ & $\begin{array}{l}\text { ISO } 9001+\text { ISO 14001; } \\
\text { ISO } 9001 \text { + OHSAS } \\
18001 ; \\
\text { ISO } 14001+\text { OHSAS } \\
18001 ; \\
\text { ISO } 9001+\text { ISO } \\
14001+\text { OHSAS } 18001 ; \\
\text { Other }\end{array}$ \\
\hline S5 & $\begin{array}{l}\text { Quality, Environmental and Occupational } \\
\text { Health and Safety policies are integrated. }\end{array}$ & $\begin{array}{l}\text { Totally disagree; } \\
\text { Disagree; Nor agree or } \\
\text { disagree; Agree; Totally } \\
\text { agree }\end{array}$ \\
\hline S6 & $\begin{array}{l}\text { Training related to management systems } \\
\text { integration had been provided to top } \\
\text { management. }\end{array}$ & "“" \\
\hline S7 & $\begin{array}{l}\text { Integration concept had been taken into } \\
\text { account during IMS implementation. }\end{array}$ & "“" \\
\hline S8 & Management system is bureaucratized. & “"” \\
\hline S9 & $\begin{array}{l}\text { The tools, methodologies and goals from } \\
\text { each management sub-system are } \\
\text { harmonized/aligned: }\end{array}$ & ""” \\
\hline $\mathrm{S} 10$ & $\begin{array}{l}\text { Top management reveals integrated } \\
\text { vision. }\end{array}$ & "“" \\
\hline $\mathrm{S} 11$ & Management procedures are integrated. & "” \\
\hline $\mathrm{S} 12$ & $\begin{array}{l}\text { Organizational interactions derived from } \\
\text { IMS implementation are perceived by } \\
\text { responsible and top management. }\end{array}$ & "“" \\
\hline Q13 & $\begin{array}{l}\text { The implementation process } \\
\text { supported on a guideline or in a }\end{array}$ & " \\
\hline
\end{tabular}

\begin{tabular}{|c|c|c|}
\hline & framework. & \\
\hline S14 & Integration occurs at a documental level. & "“" \\
\hline S15 & $\begin{array}{l}\text { Authority from Environmental and/or } \\
\text { OHS responsible is residual. }\end{array}$ & "“" \\
\hline S16 & IMS is an add-value. & "“" \\
\hline S17 & Integrated objectives are defined. & "” \\
\hline S18 & $\begin{array}{l}\text { On the company organizational structure } \\
\text { there is a clear responsible by the IMS. }\end{array}$ & “"” \\
\hline S19 & $\begin{array}{l}\text { The company monitors their processes } \\
\text { based on KPI's, MPI's and OPI's. }\end{array}$ & “"” \\
\hline S20 & $\begin{array}{l}\text { The company promoted the } \\
\text { implementation of integrated indicators. }\end{array}$ & "“" \\
\hline Q21 & $\begin{array}{l}\text { How do you classify the integration level } \\
\text { of sub-systems standards? }\end{array}$ & $\begin{array}{l}\text { Very easy; Easy; } \\
\text { Reasonable; Difficult; } \\
\text { Very difficult }\end{array}$ \\
\hline Q22 & $\begin{array}{l}\text { If the company did not had implemented } \\
\text { an IMS the overall performance } \\
\text { comparing with the actual reality would } \\
\text { be: }\end{array}$ & $\begin{array}{l}\text { Lower than the present } \\
\text { status; Equal to the } \\
\text { present status; Higher } \\
\text { than the present status }\end{array}$ \\
\hline Q23 & $\begin{array}{l}\text { How do you classify the management } \\
\text { system integration level? }\end{array}$ & $\begin{array}{l}\text { 1- Documental/2- } \\
\text { Management tools plus } \\
\text { 1)/ 3- Policies and } \\
\text { objectives plus 1) and } \\
\text { 2)/ Common } \\
\text { organizational structure } \\
\text { plus 1), 2) and 3) }\end{array}$ \\
\hline Q24 & $\begin{array}{l}\text { Audits performed to management sub- } \\
\text { systems are: }\end{array}$ & $\begin{array}{l}\text { Integrated; } \\
\text { Simultaneous, } \\
\text { Overlapped, Sequential }\end{array}$ \\
\hline Q25 & $\begin{array}{l}\text { In a } 1 \text { to } 5 \text { scale how do you characterize } \\
\text { the IMS? }\end{array}$ & $\begin{array}{l}\text { 1- Minimum integration } \\
\text { level/ 2- Low integration } \\
\text { level/ 3- Medium } \\
\text { integration level/ 4- } \\
\text { High integration level/ } \\
\text { 5- Total/Maximum } \\
\text { integration level }\end{array}$ \\
\hline Q26 & $\begin{array}{l}\text { The strategy followed during integration } \\
\text { process was: }\end{array}$ & $\begin{array}{l}\text { Sequential } \\
\text { "All In" }\end{array}$ \\
\hline Q27 & $\begin{array}{l}\text { Organizational items not susceptible of } \\
\text { being integrated are identified? }\end{array}$ & $\begin{array}{l}\text { Yes } \\
\text { No }\end{array}$ \\
\hline $\begin{array}{l}\text { Q28, } \\
\text { Q29, } \\
\text { Q30 }\end{array}$ & $\begin{array}{l}\text { The main motivations/benefits/obstacles } \\
\text { to implement the IMS were: }\end{array}$ & $\begin{array}{l}\text { Internal/ Mainly } \\
\text { internal/ External/ } \\
\text { Mainly external }\end{array}$ \\
\hline
\end{tabular}

\section{B. Experts Survey Structure}

\begin{tabular}{|c|l|}
\hline ID & \multicolumn{1}{|c|}{ Statement } \\
\hline S1 & $\begin{array}{l}\text { The predominance of internal origin motivations, obstacles and benefits } \\
\text { before, during and after the integration process. }\end{array}$ \\
\hline S2 & $\begin{array}{l}\text { Environmental manager and/or OHS manager responsibility is not } \\
\text { residual and formally there's a clear responsible by the IMS on the } \\
\text { company organizational structure. }\end{array}$ \\
\hline S3 & $\begin{array}{l}\text { The company monitors their processes based on integrated indicators } \\
\text { (KPI's, MPI's and OPI's). }\end{array}$ \\
\hline S4a & $\begin{array}{l}\text { Workers have the perception that the management system overall } \\
\text { performance is superior in an integrated context and that top } \\
\text { management reveal integrated vision. }\end{array}$ \\
\hline S4b & $\begin{array}{l}\text { Workers have the perception the integrated system is an add value and } \\
\text { the company performance would be lower in a non integrated context. }\end{array}$ \\
\hline S5 & The identification of organizational items not susceptible of integration. \\
\hline S6 & Integrated audits performed on the management system. \\
\hline S7 & An "all in" sequence integration versus a sequential process. \\
\hline S8 & $\begin{array}{l}\text { Same organizational tools and methodologies between sub-systems and } \\
\text { objectives alignment. }\end{array}$ \\
\hline S9 & Implementation process supported on a guideline or in a framework. \\
\hline S10 & $\begin{array}{l}\text { Implementation responsible has the opinion that sub-system standards } \\
\text { are easy or relatively easy to integrate. }\end{array}$ \\
\hline S11 & $\begin{array}{l}\text { The company has an integrated policy of Quality, Environment and } \\
\text { Occupational, Health and Safety and management procedures are } \\
\text { integrated as well. }\end{array}$ \\
\hline S12 & $\begin{array}{l}\text { Integration does exist at a documental level and workers have the } \\
\text { perception that the system is bureaucratized. }\end{array}$ \\
\hline S13 & $\begin{array}{l}\text { Integration level perception from the workers matches with the real } \\
\text { integration level achieved by the organization. }\end{array}$ \\
\hline
\end{tabular}

